\title{
DETERMINANCE OF CONSUMER BEHAVIOR IN CONSUMING ORGANIC RICE AT PALEMBANG CITY OF SOUTH SUMATRA, INDONESIA
}

Arbi M.

JI. Raya Palembang-Prabumulih KM 32 North Indralaya Ogan Ilir, South Sumatra, Indonesia

E-mail: arbiunsri@yahoo.com

\begin{abstract}
Organic farming is a farming activity which is familiar with the environment. Organic farming is trying to minimize the negative impact to the natural environment. The main characteristic of organic farming is the use of relatively local varieties followed by the use of organic fertilizers and organic pesticides. Organic farming is a requirement of the time, even as a future agriculture for humans as the ultimate consumers of agricultural products will feel safe and secure, especially since the human consciousness to keep sustaining the environment was further increased. Based on the above problem, the purpose and usefulness of this research are as follows: 1) Describe the characteristics of organic rice consumer in Palembang, 2) Analyze the consumer behavior of consuming organic rice in Palembang, 3) Find out What factors most influence consumer behavior in consuming organic rice in Palembang. The result that 1) Two basic factors affecting consumer behavior are internal and external factors. Internal factor consists of gender, age, family members, education level, type of work, income level, and consumption, while external factors made up the social and cultural factors, 2) From the data obtained, age about 56-65 years old are the most likely to consume an organic rice in Palembang, 3) On the basis on gender, female are higher up consuming organic rice than male. Basically a factor that affects consumers is two kinds, it is internal and external factors. To invite consumers to buy organic rice in terms of internal necessity of support as well as the motives from the family or the closest relation to improve healthy living patterns, whereas an external aspect to build a healthy living conditions in the neighborhood to live on the family or neighbours.
\end{abstract}

\section{KEY WORDS}

Organic, farming, rice, health, public service.

Health is a very important thing for humans to maintaining alive and to run activities. A lot of factors that affect human health both internal and external factors. Choosing a good food is one way to implement healthy lifestyle. Rice is the most abundant food portion of our body, which is about $60-70 \%$ of the total food we eat every day, therefore rice has an important role in keeping our bodies healthy and fit. Organic rice is rice that has been trusted as a rice is free of carcinogens, so it is very good for health. Currently, there are many producers (farmers) who produce conventional rice (using synthetic or chemical pesticides), consuming food that contain carcinogens such as rice can induce and stimulate the growth of cancers in the human body. This is how to distinguish organic and non-organic rice:

Table 1 - The difference of organic and non-organic rice

\begin{tabular}{lll}
\hline No. & Organic Rice & Non-Organic Rice \\
\hline 1. & Rough & $\begin{array}{l}\text { Physically slick, shiny, rough, and sometimes detected } \\
\text { chemical or detergent }\end{array}$ \\
\hline 2. & Dull or blur & When soaked, the dishwater became whitish \\
\hline 3. & Odorless & $\begin{array}{l}\text { Produce a white powder into the hands while the rice is still } \\
\text { dry }\end{array}$ \\
\hline $4 . \quad \begin{array}{l}\text { Contains glucose, tastes sweeter } \\
\text { chewed repeatedly }\end{array}$ & Flavorless and tasteless \\
\hline 5. & Sticky when cooked & If cooked, it's like dry rice \\
\hline 6. & More durable & More stale \\
\hline
\end{tabular}

Source: Purwaningsih, 2009. 
Basically an organic product are not expensive when compared to the cost of healthy care must we pay with often consume products containing chemicals or carcinogens. The consumer behavior in consuming organic rice is an attempt or actions when it 9 to foodstuffs especially rice, one of the theories that have attempted to reveal the determinants of behavior analysis of the factors that affects the behavior of it is because there are four principal reasons, it is thinking and feelings (including knowledge, beliefs, attitudes, values), references (friends, relation, media information, etc.), resources (income, time, effort, etc.), culture (ethnic), and physical (age, genders, etc.).

Palembang is one of the major cities in the province of South Sumatra. As a large city with a total population of approximately $1,452,840$ inhabitants with a population density of 4.052 inhabitants/Km2 must have a large amount of food. In consuming food, most of the people in Palembang have already started trying to switch to a type of food that is believed to be keeping a healthy. Rice is a staple food that is consumed daily most of even the entire population of Palembang. All this time the rice consumers in Palembang only pays attentioñn to physical appearance, the packaging and the good prices. However, with a knowledge and a change of attitude from some consumers in Palembang, now it's been a lot to choose or buy a quality product that is organic rice. The making of such behavioral changes does not take away from economic, social, and health knowledge. With this basic researchers are interested in conducting research on factors that affect consumer decisions in selecting organic rice to be consumed daily. Based on the above description, an interesting problem to examined in this study is as follows:

- What are the characteristics of an organic rice consumer in Palembang?

- How does consumer behavior get to consume organic rice in Palembang?

- What factors most influence consumer behavior in consuming organic rice in Palembang?

\section{METHODS OF RESEARCH}

This research held in Palembang, Indonesia. The selection of the location was deliberately purposive by considering that Palembang is one of the most numerous cities in South Sumatra Province more that the other city in the region of South Sumatra so that the characteristics of the household population is more diverse. This research was carried out in one of the largest distributors of organic rice in Palembang in 'Gerai Pasar Tani' from Ministry of Agricultural Crops and Holticulture in the Southern State of Sumatra.

According to Sugiono (2010), research variable is basically everything that shaped what researches are set apart to learn so that the retrieved information about the matters, then drawing conclusions. In this research there is one variable that the factors can influence consumer behavior in consuming organic rice. With a sub variable covering the family income, education, health reasons as measured by giving questionnaire to the consumer who are visiting at the place of sale that provides organic rice.

The methods used in this research are survey method. The survey method was used because it was safe to do the primary data collection using a questionnaire with a direct interview to respondents (consumer) so there is immediate interaction.

Sampling methods used in this research are Accidental Sampling Methods, which are accidental sampling by taking cases or respondents who happen to be existing or available at this place with the context of research (Natoatmodjo, 2010). Rosceo in Utari (2014) gives advice on sample size in the research between 30 up to 500 , because the population is unknown, it will be taken as many as 30 respondents considered worthy to collect the necessary data and represent the population. In this process of sampling at a research location, the respondents would be the source are the consumers making the repurchase, it is assumed that the consumer has consumed organic rice.

To answer the first objective is to know the consumer characteristic of organic rice in Palembang, researchers are asking questions in direct order with the systematic questionnaire that has been systematically complied, then answered by the respondent sample and developed into descriptive writing with the frequency tabulation. The 
characteristics and consumers who consume organic rice are seen by age, family members, education levels, type of work, income, consumption, and health benefit perception. To answer the second objective is how the consumer behavior in consuming organic rice in Palembang, then used a descriptive analysis through the table analysis and a description based on qualitative data. To answer the third objective is what factors influence on consumer behavior in consuming organic rice using descriptive analysis of the data that is already collected to get the answers from the problem. The analysis steps in the descriptive method is to determine the value of Mean (M), Median (Me), and Mode (Mo). In order to create a grouping category, it first has to determine the width and the number of the intersections. According to Sutrisno Hadi (1985:12) the width of the interval can be determined by measuring the distance divided by the number of intervals. In this research, the range of measurements obtained from the highest score to the lowest score, then divided by the amount of the desired interval in this study is four. The data analysis technique used is a descriptive feature with percentage. The percentage of useful to know the score obtained, then the magnitude of the level of implementation can be searched by a percentage that is by comparing the frequency statement with the amount of respondents, then multiplying $100 \%$. As for the formula:

$$
P=F / N \times 100 \%
$$

Where: $P=$ percentage, $F=$ frequency.

\section{RESULTS AND DISCUSSION}

Palembang is the capital city of the South Sumatra Province and geographically located between 2o 52' to 3o 5' South Latitude and 104o 37' to 104o 52' East longitude with an average height of 8 feet from the sea. The entire city of Palembang is based on PP No.23, 1988 of $400,61 \mathrm{~km} 2$ or $40.061 \mathrm{Ha}$ which is divided into 16 administrative districts and 107 villages.

Topography The topography of Palembang is generally a lowland with an average elevation of approximately $4-12$ feet above the sea, with the composition of $48 \%$ of the soils that are not flooded, $15 \%$ of the soils is seasonal, and $35 \%$ of the soils are continuous throughout the season.

Palembang is distinguished into areas with topographical horizontally to the baseboard, with the tilt of range between $0-30$ and undulating topography with the tilt range between 2 $-10 \mathrm{o}$. Most of Palembang is a lowland with elevation of land an average of approximately 12 feet above the sea.

Table 1 - Average Temperature and Humidity according to the Month In Palembang in 2017

\begin{tabular}{ccccccc}
\hline \multirow{2}{*}{ Month } & \multicolumn{3}{c}{ Temperature } & \multicolumn{2}{c}{ Humidity } \\
\cline { 2 - 7 } & Max & Min & Average & Max & Min & Average \\
\hline January & 32,9 & 24,9 & 27,5 & 94,9 & 68,1 & 85,4 \\
February & 32.3 & 24,6 & 27,2 & 94,9 & 70,9 & 85,8 \\
March & 33,1 & 24,9 & 27,8 & 94,9 & 67,9 & 85,1 \\
April & 33,5 & 25,2 & 28,1 & 94,6 & 68,7 & 85,1 \\
May & 33,4 & 25,5 & 28,2 & 95,5 & 67,3 & 85,1 \\
June & 33,0 & 24,9 & 27,8 & 93,6 & 64,6 & 82,6 \\
July & 33,6 & 24,6 & 27,9 & 94,0 & 60,4 & 80,8 \\
August & 33,9 & 24,8 & 28,3 & 90,8 & 56,2 & 76,7 \\
September & 33,6 & 24,2 & 27,7 & 92,5 & 60,8 & 80,9 \\
October & 33,0 & 24,3 & 27,6 & 93,3 & 63,1 & 82,2 \\
November & 32,7 & 24,6 & 27,7 & 93,9 & 63,6 & 82,7 \\
December & 32,4 & 24,3 & 27,5 & 94,9 & 66,1 & 83,5 \\
\hline
\end{tabular}

Source: Meteorology, climatology, and geophysical agency Kenten Palembang.

Based on the data of the central statistics 2017, the population in Palembang are 1.602.071 people made up of 802.990 male and 799.081 female. The sex ratio in Palembang 
in 2016 of 100.489 percent, which means that there are the amount of male population more than the female population. For districts, the highest sex ratio is found in Plaju of 103.686 percent, while the lowest sex ratio in East Ilir I of 94.673 percent.

Organic rice consumption patterns is the habit of consuming organic rice that consumers conducted in his family. In this research, there are 3 distinct patterns of organic rice consumption, that is, regular basic, mix, and sometimes. Consuming routine in this research is a situation where consumers consume organic rice continuously without being mixed with non-organic rice. In this research it consumed mixture is divided into two, mixing with other rice and mixing with other food. Sometimes consume in this case, the circumstances where consumers don't consume organic rice continuously or have a tube of time before consuming again. The consumer behavior of organic rice based on the consumption patterns in the family can be presented in the table:

Table 2 - Consumer behavior of organic rice by consumption patterns in the family

\begin{tabular}{cccc}
\hline No & Consumption Patterns & Respondents & Percentage (\%) \\
\hline 1 & Routine & 23 & 76,67 \\
2 & Mix & 6 & 20,00 \\
3 & Sometimes & 1 & 3,33 \\
\hline & Total & 30 & 100,00 \\
\hline
\end{tabular}

In general, the person who has an eating frequency in a day consists of three main meals that is breakfast, lunch, and dinner. In this research, the range of responder's consumption viewed from the average intensity of the respondent's consume rice from organic in one day. Consumer behavior of organic rice based on the consumption frequency can be seen in the table.

Table 3 - Consumer behavior of organic rice by the consumption frequency in one day

\begin{tabular}{cccc}
\hline No & Consumption frequency per day & Respondents & Percentage (\%) \\
\hline 1 & One time & 2 & 6,67 \\
2 & Twice & 12 & 40,00 \\
3 & Three times & 16 & 53,33 \\
\hline & Total & 30 & 100,00 \\
\hline
\end{tabular}

Consumer behavior represents the individual make decisions to use their available resources (time, money, effort) in order to buy things related to consumption. The behavioral science is the science of how an individual is making decisions in the use of resources, it is time, energy, and money to consume something, including learning what, why, when, and where someone buying, and how often someone buys and uses a product. According to Engel (1994), the consumer behavior in making purchase decisions are going to five stages. It is introduction of needs, information retrieval, information evaluation, purchase, and post purchase. Consumer purchase decision making process is affected by three main factors, that is 1) individual differences consisting of consumer resources, motivation and involvement, knowledge, attitudes, personality, lifestyle, and demographics. 2) Environmental factors made up of culture, social class, personal influence, family, and situations. 3) The psychological process consists of information processing, learning, a change of attitude/behavior. Consumer behavior in consuming organic rice $\mathrm{n}$ Palembang in the research provides purchase patterns behavior, consumption format, and purchase frequency.

\section{CONCLUSION}

There are two consumer decision processes to purchase or consuming goods and services, it is: 1) Difference and influence of individual, 2) Environmental impact and psychological influence. In general, the household has a supply of rice because it was strongly influenced by cultural factors, where rice should be available at least the minimum needs to eat for one day. This culture arose because rice is considered a very important food 
source. So, there are three conclusion 1) Two basic factors affecting consumer behavior are internal and external factors. Internal factor consists of gender, age, family members, education level, type of work, income level, and consumption, while external factors made up the social and cultural factors. 2) From the data obtained, age about 56-65 years old are the most likely to consume an organic rice in Palembang 3 ) On the basis on gender, female are higher up consuming organic rice than male.

\section{REFERENCES}

1. Bangun HPP. 2013. Analisis Pola Konsumsi Pangan and Tingkat Konsumsi Beras di Desa Sentra Produksi Padi. Skripsi. Universitas Sumatera Utara, Medan.

2. Fitriani. 2015. Perubahan Sosial Ekonomi Masyarakat di Kecamatan Panumbangan Ciamis. Universitas Pendidikan Indonesia. [Diakses pada tanggal 02 Oktober 2017] http://repository.upi.edu/

3. Gultom L, Ratna W and Siti J. 2014. Analisis Efisiensi Usahatani Padi Semi Organik di Kecamatan Cigombong Bogor. Institut Pertanian Bogor, Bogor. Jurnal Informatika Pertanian. 23 (1): 7 - 18.

4. Haliana N. 2009. Analisis Faktor - Faktor Yang Mempengharui Konsumen Dalam Pengambilan Keputusan Pembelian Produk Mie Instan Merek Indomie. Universitas Gunadarma, Jakarta. Jurnal Manajemen and Bisnis.

5. Ikasari DM, Panji D, Rizky LRS, and Ardaneswari DPC. 2016. Analisis Faktor - Faktor yang Mempengharui Perilaku Konsumen dalam Pengambilan Keputusan Pembelian Beras Organik. Universitas Brawijaya, Malang. Jurnal Teknologi Pertanian. 17(1): 69-78. [Diakses pada tanggal 01 November 2017]

6. Indriani L. 2015. Pengaruh Pendapatan, Gaya Hidup and Jenis Kelamin Terhadap Tingkat Konsumsi Mahasiswa Fakultas Pertanian Universitas Negeri Yogyakarta. Skripsi. Universitas Negeri Yogyakarta, Yogyakarta.

7. Kusumastuti Y. 2013. Pengaruh Word of Mouth (WOM) and Persepsi Kualitas Terhadap Keputusan Pembelian Produk. Skripsi. Universitas Sebelas Maret, Surakarta.

8. Lastry Y. 2006. Analisis Pola Konsumsi Beras Rumah Tangga di Kota Bogor. Skripsi. Institut Pertanian Bogor, Bogor.

9. Manuhutu M and BT Wahyu. 2005. Bertanam Sayuran Organik Bersama Melly Manuhutu. Jakarta: Agromedia Pustaka

10. Natoatmodjo. 2010. Metode Penelitian Kesehatan. PT Rineka Cipta: Jakarta.

11. Nugraheni S. 2015. Produksi Padi Berkelanjutan. http://distan.jabarprov.go.id [Diakses pada tanggal 01 November 2017].

12. Pradesha A. 2004. Analisis Perubahan Pola Konsumsi Beras Rumah Tangga Setelah Dihapuskan Tunjangan Beras Secara Natura. Skripsi. Institut Pertanian Bogor, Bogor.

13. Prayoga S. 2016. Perilaku Konsumsi Beras Organik di Kota Palembang. Skripsi (tidak dipublikasikan). Universitas Sriwijaya, Palembang.

14. Priyanto R. 2007. Faktor - Faktor yang Mempengharui Tingkat Konsumsi Rumah Tangga Karyawan PT ASKES (Persero) Cabang Jember. Skripsi. Universitas Jember, Jember.

15. Purwaningsih B. 2009. Faktor - Faktor Yang Mempengharui Pola Perilaku Konsumsi Beras Organik. Skripsi. Universitas Sebelas Maret, Surakarta.

16. Putri J. 2002. Analisis Ekonomi Pola Konsumen Beras Organik Konsumen Rumah Tangga. Skripsi. Institut Pertanian Bogor, Bogor.

17. Rosmawati H. 2016. Analisis Komparatif Pendapatan Usahatani and Marjinal Pemasaran Padi Sawah Organik dengan Anorganik di Desa Sumbersuko Jaya Kecamatan Belitang Kabupaten OKU Timur. Proposal Penelitian. Universitas Baturaja, Baturaja.

18. Schiffman GL and LL Kanuk. 2008. Perilaku Konsumen. Edisi Ketujuh. Jakarta: Indeks Gramedia.

19. Setiadi NJ. 2008. Perilaku Konsumen Konsep and Implikasi Untuk Strategi and Penelitian Pemasaran. Jakarta: Kencana Prenada Media Press.

20. Sulistyana P, JH Mulyo and Jamhari. 2014. Konsumsi Beras Organik Pada Tingkat Rumah Tangga di Kota Yogyakarta. Jurnal Agro Ekonomi. 24(1): 25 - 34. 
21. Sumarwan U. 2004. Perilaku Konsumen Teori and Penerapannya Dalam Pemasaran. Bogor: Ghalia Indonesia.

22. TB Tulus. 2003. Perkembangan Sektor Pertanian Indonesia. Jakarta: Ghalia Indonesia.

23. Utami D. 2011. Analisis Pilihan Konsumen Dalam Mengkonsumsi Beras Organik di Kabupaten Sragen. Jurnal IImu - IImu Pertanian MEDIAGRO. 7(1): 35 - 46.

24. Utari W. 2014. Pengaruh Kualitas Layanan, Harga, Varian Obat and Fasilitas Terhadap Kepuasan Pelanggan Apotek Yakersuda Bangkalan. Jurnal NeO-Bis. 8(1).

25. Wahyudin I. 2008. Analisis Perbandingan Kandungan Karbohidrat, Protein, Zat Besi and Sifat Organoleptik pada Beras Organik and Beras Non Organik. Skripsi. Universitas Muhammadiyah Surakarta, Surakarta.

26. Wahyuy W. 2017. Mau Beras Organik Sehat and Murah ? Beli di Sini. Tribun Sumsel. 17 Maret 2017. http://sumsel.tribunnews.com. (Diakses pada tanggal 21 November 2017).

27. Widyawati PS, Anita MS, Thomas IPS, Pricilia M, William S and Christian L. 2014. Pengaruh Perbedaan Warna Pigmen Beras Organik Terhadap Aktivitas Antioksidan. Universitas Katolik Widya Mandala, Surabaya. Jurnal Agritech. 34 (4): 399 - 406. 